\title{
The Kinship Terminology in Ruthenian, Slovak, and Serbian*
}

\author{
MIHAJLO FEJSA \\ Univerzitet u Novom Sadu, Odsek za rusinistiku, Dr Zorana Đinđića 2, SRB-21000 Novi Sad \\ E-mail: fejsam@gmail.com
}

(Received: 26 February 2017; accepted: 15 April 2017)

\begin{abstract}
The aim of this paper is to present the kinship terminology in the Ruthenian language and compare it with the kinship terminology in Slovak and Serbian. Some 270 years ago, groups of Ruthenians began migrating south from their homeland in the Carpathian mountains mostly from Zemplen and Šaroš counties (in present-day Slovakia) to the Bačka region (in present-day Serbia). Since the Ruthenian language has been in contact both with the Slovak and Serbian languages for a long time, we expect to find certain influence of these languages on the Ruthenian kinship terminology.
\end{abstract}

Keywords: kinship terminology, Ruthenian, Slovak, Serbian, languages in contact

\section{Introduction}

Before the ancestors of the Vojvodina Ruthenians (or Rusyns), in total number of around 2.000, were allowed to settle under the contract with the state authorities to Kerestur (1751) and Kucura (1763), villages in the central Bačka region, in the middle of the 18th century, they had lived within the borders of the Hungarian Kingdom (Хорњак 2006: 25). As the Ruthenian population increased in time, from the end of the 19th century, many of them started to migrate from Ruski Krstur and Kucura to Kula, Vrbas, Novi Sad, and Đurđevo in Bačka as well as Šid and Sremska Mitrovica in Srem in pursuit of jobs and better life. The contacts of the Ruthenians and the Serbs increased in time as well (ФEJCA 2010: 7).

The research of kinship relations in the Ruthenian language is almost unique since the terminology of kinship relations was dealt with only in the Serbian-Ruthenian Dictionary (РАмАч 1995-1997) and the Ruthenian-Serbian Dictionary (РАMAч 2010). The terms of Ruthenian kinship relations from these two major lexicographical works were included in the questionnaire and offered to schoolchildren of the 8th grade in Ruski Krstur and Kucura in 2014. The schoolchildren were asked if they heard certain terms and if they used them. They were also asked to define the meanings of the terms (ФЕЙСА 2014: 95). The research showed that the Serbian system of kinship relations is more complex and that it exerts great influence on the Ruthenian system of kinship relations.

* This paper is a product of projects № 187002 and 187017 funded by the Ministry of Science of the Republic of Serbia. 
The aim of this paper is to compare the Ruthenian, Slovak, and Serbian terminology of kinship relations since the Ruthenians have lived with the Slovaks and the Serbs for a long time (cf. the terms for the Slovak language in LALIKOVÁ 1989, Макишова 2004, Maкišova-Tyrova 2015, and the terms for the Serbian language in Vuković 1980, MARJANović-SAVIĆ 1982, БJEлЕTић 1994). The list of terms for the Serbian language includes 65 items (SAVIĆ-RADOviĆ 2014).

\section{The terms for family members older than parents}

\begin{tabular}{|c|c|c|}
\hline Ruthenian terms & Slovak terms & Serbian terms \\
\hline & prastarí rodičia & \\
\hline prađido & prastarý otec & praded, pradeda \\
\hline prababa & $\begin{array}{l}\text { prastará matka, prastará } \\
\text { mat' }\end{array}$ & prababa \\
\hline & starí rodičia, fam. starkí & \\
\hline đido, fam. stari ocec & $\begin{array}{l}\text { starý otec, fam. starý oco, } \\
\text { starý ocko, hovor. starký }\end{array}$ & ded \\
\hline baba, fam. stara mac & $\begin{array}{l}\text { stará mat', stará matka, } \\
\text { hovor. stará mama, starká }\end{array}$ & baba \\
\hline
\end{tabular}

As this table shows, the terms for the father's / mother's father and the father's / mother's mother are similar in Ruthenian and Serbian (Ruth. đido and baba, Serb. deda and $b a b a$ ). In Slovak, the terms are formed by adding the adjectives stary and stara 'old' before otec and mat'. Parallel constructions were used in Ruthenian in the past (stari ocec and stara mac). These constructions originate from the time when the Ruthenians and Slovaks lived together in the Carpathian area before the settlement in Bačka in the middle of the 18th century.

As it can be seen in the table above, the Slovak language has several other terms for a grandfather and a grandmother but they are familiar (starý oco, starý ocko; stará mama) and spoken (starký, starká) ones. In the Ruthenian language, the diminutives đidko and đidočok, or babka and babočka are frequently used, although their use is primarily related to children's speech. Their equivalents in the Serbian language are deka, dedica, and sometimes čiča, or baka and bakica.

In the Ruthenian, Slovak, and Serbian languages, the names for the grandparents' parents are formed by adding the prefix pra-. Hence, the persons more remote than a grandparent are prađido and prababa in Ruthenian, pradeda and prababa in Serbian, and prastari otec and prastara matka, together with pradedo and prababka (MAKIŠOvA-TYRova 2015: 36), in Slovak. The terms for a great-grandfather and a great-grandmother are formed by adding another prefix pra- (for example, praprađido and praprababa in Ruthenian). It is interesting that the Serbian speakers, mainly through oral tradition, have kept for centuries the archaic names for the ancestors from the 4th to the 16th degree of kinship: (4) čukundeda and čukunbaba; (5) navrdeda and navrbaba; (6) kurđel and kurđela; (7) askurđel and askur- 
đela; (8) kurđun and kurđuna; (9) kurlebalo and kurlebala; (10) sukurdol and sukurdola; (11) sudepač and sudepača; (12) parđupan and parđupana; (13) ožmikura and ožmikurka; (14) kurajber and kurajbera; (15) sajkatava and sajkatavka; (16) beli orao and bela orlica. This is not the case in Ruthenian and Slovak. The Ruthenians rarely use the terms čukunđido and čukunbaba, whereas askurđel is used only in a couple of swearing expressions by older generations (for example, askurđela/bogara ci iščce; see PAMAч 1995: 17) without a clear idea which degree of kinship the speakers refer to.

\section{The terms for family relations in the narrow sense}

\begin{tabular}{|l|l|l|}
\hline \multicolumn{1}{|c|}{ Ruthenian terms } & \multicolumn{1}{c|}{ Slovak terms } & \multicolumn{1}{c|}{ Serbian terms } \\
\hline rodiči, roditelje & rodičia & roditelji \\
\hline $\begin{array}{l}\text { ocec, beš. tato, apo, dem. } \\
\text { tatko }\end{array}$ & $\begin{array}{l}\text { otec, fam. otecko, oco, } \\
\text { ocko, ocino, ocinko, ocík }\end{array}$ & otac \\
\hline $\begin{array}{l}\text { mac, } \text { beš. mama, dem. } \\
\text { mamka, zast. matka }\end{array}$ & $\begin{array}{l}\text { matka, mat', mater, hovor. } \\
\text { mama, fam. mamka, } \\
\text { mamička, mamulienka }\end{array}$ & majka, mati, mater \\
\hline dzeci & deti & deca \\
\hline sin, dem. sinočok & syn, fam. synček, synáčik & sin \\
\hline $\begin{array}{l}\text { dzivka, fam. dzivče, zast. } \\
\text { cera }\end{array}$ & $\begin{array}{l}\text { dcéra, fam. dcérka, } \\
\text { dcéruška, dcérenka }\end{array}$ & kći \\
\hline braca i šestri & súrodenci & braća i sestre \\
\hline brat, fam. bracik & brat, fam. braček, bratko & brat \\
\hline šestra, fam. šestrička & sestra, fam. sestrička & sestra \\
\hline $\begin{array}{l}\text { unučata } \\
\text { unuče }\end{array}$ & $\begin{array}{l}\text { vnúčatá } \\
\text { vnúčence }\end{array}$ & $\begin{array}{l}\text { unučad } \\
\text { unuče }\end{array}$ \\
\hline unuk & vnuk, fam. vnúčik & unuk \\
\hline unuka & vnučka & unuka \\
\hline njevlasni ocec & nevlastný otec, otčim & očuh \\
\hline njevlastna mac, mačoha & $\begin{array}{l}\text { nevlastná mat', nevlastná } \\
\text { matka, macocha }\end{array}$ & maćeha \\
\hline njevlasni sin & nevlastný syn & posinak, pastorak \\
\hline njevlasna dzivka & nevlastná dcéra & poćerka, pastorka \\
\hline
\end{tabular}

As this table shows, the term for a male child to parents, i.e. a son (Ruth. sin, Slov. syn, Serb. sin) and the term for a male child born by the same parents, i.e. a brother (Ruth. brat, Slov. brat, Serb. brat) are the same in the three investigated languages. The terms for the son's / daughter's son, i.e. a grandson (Ruth. unuk, Slov. vnuk, Serb. unuk) and the terms for a female child born by the same parents, i.e. a sister (Ruth. šestra, Slov. sestra, Serb. sestra) are very similar.

In addition to the dominant term for a male child to parents, there are many familiar and diminutive forms such as sinočok and sinok, and the archaism fijam, 
which is of Hungarian origin (ANDRIĆ 2014: 13, PAMAY 2010: 797). The noun hlapec 'boy' and its diminutive hlapčik can also be used for this purpose (Ruth. Voni maju dvoh hlapcoh 'They have two sons'). A diminutive form takes over the function of the term sin in the Serbian language as well. Hence, in addition to the noun sin in this function, we can find the term dečak (Serb. Oni imaju dva dečaka 'They have two sons') and the nouns sinak, mališan, and klinac.

There are a number of variants for a female child to parents as well. A female descendant in Serbian is called kći, kćer, kćerka or ćerka but in the same function we can find the noun devojčica (Serb. Ima jednu devojčicu 'He has a daughter'). In Ruthenian, the situation is more complicated for several reasons. Firstly, because the term cera from Ruthenian folk songs, which corresponds to Serbian term ćerka and Slovakian term dcera (МАкишова 2004: 159), joined the lexicon of archaisms. The term cera is probably shortened from Slovak dcera. It was recorded in the late 19th century in Volodimir Hnaćuk's ethnographic collections (PAMAY 1983: 191). Secondly, the most frequent term dzivka alternates with the term dzivče (Ruth. Ma jedno dzivče 'She has a daughter'). Thirdly, in the Ruthenian language, the lexeme dzivka means not only a daughter (Serb. ćerka) but also a girl (Serb. cura, devojka) and a loved person, i.e. a girlfriend (Serb. dragana, voljena osoba). Thus, in Ruthenian, three correspondent relationships can be established: 1. dziv$k a$ : daughter; 2. dzivka: girl, 3. dzivka: girlfriend. There are several terms for parents used instead of the common ones in all three languages. For example, most members of the Ruthenian national community, in addition to the term ocec, use the alternative, familiar term tato, and the diminutives tatko and tatocko. As far as the mother is concerned, the term mac is often replaced by the familiar term mama, and the diminutives mamka and mamočka. Young people use the terms čale and keva (ФЕJCA 2012: 180-181), which represents direct Serbian influence. There also exist two old terms for parents: apo and matka (РАMAч 2010: 38, 379). The first term is borrowed from Hungarian (ANDRIĆ 2014: 11) and the second one is shared with Slovak. The Slovak language has more familiar terms for parents than the other two languages: otecko, oco, ocko, ocino, ocinko, ocik; mamka, mamička, mamulienka. Hypocoristics for a male parent in Serbian are mostly tatica, taja, tajo, and tale, and for a female parent - mamica, majčica, and nana.

The same happens with the terms for children, that is for a brother and a sister. The terms brat and šestra are used by each member of the Ruthenian national community. Young people, however, use a number of other lexemes. For example, instead of the term brat, they mainly use the diminutive bracik, and also bratija, brašo, burazer, or tebra, the shortened forms of bracik and burazer, i.e. braco and buraz, as well as innovative terms such as brader, bro, and bruda (the first two are Anglicisms, and the third is probably a Germanism). Instead of the term sestra, young people use the diminutives šestrička, seka, seja, and the Anglicism sister (ФЕJCA 2012: 183). The Serbian influence is evident.

It has already been mentioned that the terms for naming the children of our children in Ruthenian, Slovak, and Serbian are similar, and there is also a term in these three languages which does not include gender determination and may be 
used for a grandson and a granddaughter at the same time: Ruth. unuče, unučatko; Serb. unuče; Slov. vnučence.

In the investigated languages, the next, third degree of kinship is formed by adding the prefix pra-. In Ruthenian and Serbian, the term for a boy is praunuk and it is praunuka for a girl. In Slovak, it is pravnuk for a boy and pravnuka for a girl (MAKIŠOva-TYRova 2015: 35). For marking the fourth degree of kinship, the prefix pra- is doubled (for example, prapraunuk); in Ruthenian and Serbian, the prefix čukun- is used as well (for example, čukununuk).

Generally speaking, the greatest similarity is observed in the terms referring to the family in the narrow sense. A previous study on the terms that mark family relations showed that the most frequent lexemes in the Ruthenian language are ocec, mac, dido, sin, dzivka, brother, and sister (ФЕйСА 2014: 96). This can be stated for Serbian and Slovak as well.

\section{The terms for family relations in a broader sense}

\begin{tabular}{|l|l|l|}
\hline \multicolumn{1}{|c|}{ Ruthenian terms } & \multicolumn{1}{c|}{ Slovak terms } & \multicolumn{1}{c|}{ Serbian terms } \\
\hline bači, fam. striko & $\begin{array}{l}\text { strýk, strýc, strýko, } \\
\text { fam. strýčko }\end{array}$ & stric \\
\hline andja & stryná, fam. strynka & strina \\
\hline bači, fam. ujko & ujec, ujček, fam. ujo, ujko & ujak \\
\hline andja, fam. teta & $\begin{array}{l}\text { ujčiná, fam. ujčinka, teta, } \\
\text { fam. tetka, tetuška }\end{array}$ & ujna \\
\hline švekor & svokor & svekar \\
\hline švekra & svokra & svekrva \\
\hline ženov ocec & test' & tast, punac \\
\hline ženova mac & testiná & tašta, punica \\
\hline mužov brat & zast. dever, švagor & dever \\
\hline mužova šestra & zast. zolvica, švagriná & zaova \\
\hline šovgor & švagor & šurak, šogor \\
\hline nina & švagriná & svastika \\
\hline $\begin{array}{l}\text { muž ocovej/macerovej } \\
\text { šestri }\end{array}$ & svák, sváko & tetak \\
\hline bratnjak & synovec, fam. synovček & $\begin{array}{l}\text { bratanac, bratić, sinovac, } \\
\text { nećak }\end{array}$ \\
\hline šestrinjica & neter & bratanica, sinovica, nećaka \\
\hline bratnjak & synovec & sestrić, nećak \\
\hline šestrinjica & neter & sestričina, nećaka \\
\hline bratnjak & bratanec, bratranec & ujaković, ujčević \\
\hline bratnjak & bratanec, bratranec & bratanac, stričević \\
\hline bratnjak & bratanec, bratranec & tetić, tetkić \\
\hline šestrinjica & sestra od ujaka \\
\hline & & \\
\hline
\end{tabular}




\begin{tabular}{|l|l|l|}
\hline šestrinjica & sesternica & bratučeda, stričićna \\
\hline šestrinjica & sesternica & tetićna, tetična \\
\hline žec & zat',fam. zat'ko & zet \\
\hline njevesta & nevesta & snaha \\
\hline svat & svat & prijatelj \\
\hline svaha & svatka & prija \\
\hline$[$ kresni] kum & krstný otec, hovor. krstný & krsni kum \\
\hline$[$ kresna] kuma & $\begin{array}{l}\text { krstná matka, krstná mat', } \\
\text { hovor. krstná mama, krstná }\end{array}$ & kuma \\
\hline kumče & krstný syn & kumče \\
\hline kumče & krstná dcéra & kumče \\
\hline
\end{tabular}

As far as the terms for family relations in a broader sense are concerned, the Serbian terminology is the most complex one and the Ruthenian terminology is the simpliest one. For example, the Ruthenian term bači covers the terms stric, ujak, and tečo in Serbian, and strýk and ujec in Slovak. In the Serbian language, we must take into account whether the family relationship is established through the female or the male line, not only in relations that occurred by blood but also in relations that occurred by matrimonial bond. Therefore, when we use the terminology of kinship relations, we must have in mind if a person is the father's or the mother's brother, respectively, stric or ujak. The term for the wife of his father's brother is strina, and the term for the wife of his mother's brother is ujna. Strina and ujna in Serbian, and stryná and ujčiná in Slovak are covered by the same term anđa in Ruthenian. In the Ruthenian-Serbian dictionary, there are eight meanings in the entry anđa: 1 . the brother's wife (Serb. snaha, snaja, deverka); 2. the wife's brother's wife (Serb. šurakinja, šogorica); 3. the father's brother's wife (strina); 4. the mother's brother's wife (ujna); 5. the husband's brother's wife (jetrva); 6. the husband's married sister (zaova); 7. the wife's married sister (svastika); 8. an older woman (tetka, majka) (РАMAч 2010: 36). This example clearly illustrates how simplified the terminology for family relations in Ruthenian is.

The simplification of the Ruthenian kinship relations system in comparison to the Serbian one is particularly noticeable at the level at which the sister's and brother's children are named; the brother's son is bratanac, bratić, sinovac, nećak, the brother's daughter is bratanica, sinovica, nećaka, the sister's son is sestrić, nećak and the sister's daughter is sestričina, nećaka. The sister's and brother's male children in the Ruthenian language are called bratnjaci, and the sister's and brother's female children are called šestrinjici/šestranjici. The Slovak terminology for these relations is somewhere in the middle between Serbian and Ruthenian but closer to Serbian since there exist sinovec, neter, bratanec, and sesternica. The terms bratnjak and šestrinjica/šestranjica take a stable place in the kinship terminology system of the Ruthenian language, a study of the language of the youth, however, pointed to the use of the lexemes brat and šestra in the same meaning which is influenced by Serbian (ФЕЙСА 2014: 104). 
The case of the term teta is interesting because we cannot talk only about the immediate impact of Serbian but also about an indirect, stimulative impact due to the fact that the lexeme teta, meaning the mother's brother's wife, also exists in the Carpathian area. It exists in the Slovak language too (МАкишова 2004: 158). The terms bači and teta appear in the language of the youth as synonyms for the traditional Ruthenian terms šovgor (the wife's brother) and nina (the wife's sister). The term šovgor has its equivalents in Slovak (švagor) and Serbian (̌̌ogor) but the term nina exists only in Ruthenian.

The terms dever, šure, zaova, and šurnjaja are not a part of the Ruthenian traditional terminology system for labelling kinship relations but they may be heard by the Ruthenian language speakers, especially by those from the mixed, SerbianRuthenian marriages (ФЕЙСА 2014: 105). Considering that all Ruthenians are bilingual, Serbian influence will increase and we can assume that the use of these terms will increase in time as well.

Generally speaking, as far as the Ruthenian system of kinship terminology is concerned, at the beginning of the 21st century, the speakers of the Ruthenian language are faced with a choice between two sets of terms: on the one hand, the traditional set, in which the lexemes bači and anđa are the result of coexistence with the Hungarians in the Hungarian Kingdom or in the former Austro-Hungarian Empire and, on the other hand, a set of recent origin, whose gradual entry started with the immigration of Ruthenians to Bačka in the middle of the 18th century, after living with the Serbian population. Some elements of the Serbian system of kinship terminology, especially among young people, began to modify the traditional set. This especially applies to terms stric, strina, ujak, ujna, and teta.

Whereas the term bači is very frequent in Ruthenian, covering several kinship terms in Serbian and Slovak, it is important to add that the term exists in Slovak but it is used to address only the unknown or less known people who are not in any family relationship.

Among the terms for family relations in a broader sense which are created through marital connections, the greatest correspondence is observed in the terms for a son-in-law: Ruth. žec, Slov. zat', Serb. zet; for the husband's /wife's father: Ruth. švekor, Slov. svokor, Serb. svekar; for the husband's /wife's mother: Ruth. švekra, Slov. svokra, Serb. svekrva; for a brother-in-law (the wife's brother): Ruth. šovgor, Slov. švagor, Serb. šogor (besides šurak). Slovak and Ruthenian share the terms svat and njevesta, while Ruthenian and Serbian share the terms kum and kumče.

\section{Conclusion}

In the paper, the terms of Ruthenian kinship relations have been compared with the Serbian and the Slovak ones. The Serbian kinship relations system is the most complex one. For instance, the Ruthenian term bači covers the meanings of Serbian ujak, stric, and tečo, and the Ruthenian term anđa covers the meanings of $u j$ $n a$, strina, and tetka. The situation is similar in Slovak since the term bači covers 
the meanings of strýk and ujec. The simplification of the Ruthenian kinship relations system in relation to the Serbian kinship relations system is particularly evident at the level at which relations for the sister's and brother's children are expressed; Ruthenian bratnjak, respectively, šestrinjica/šestranjica, occur as equivalent terms to Serbian bratanac, bratić, sinovac, nećak, and sestrić, respectively, bratanica, sinovica, nećaka, and sestričina.

The Ruthenian lexeme dzivka stands out because it covers three meanings, i.e. three lexemes of the Serbian and Slovak languages: a daughter, a girl and a girlfriend (for example, Serb. 1. ćerka / kći; 2. devojčica / cura; 3. devojka/dragana).

The highest degree of similarity between the kinship terms in Ruthenian, Slovak, and Serbian is noticed in the terms conveying names of male and female persons of family relations in the narrow sense. For example, Ruth. ocec: Serb. otac: Slov. otec; Ruth. mac : Serb. majka : Slov. matka; Ruth. brat: Serb. brat: Slov. brat; Ruth. šestra: Serb. sestra: Slov. sestra; Ruth. sin: Serb. sin: Slov. syn; Ruth. unuk: Serb. unuk: Slov. vnuk; Ruth. unuka: Serb. unuka: Slov. vnučka.

Most of the terms of Ruthenian kinship relations are of Slavic origin but there are several Hungarisms (bači, anđa, apo, fijam) and a Germanism (šovgor). The obsolete lexeme cera is etymologically connected to the Slovak lexeme dcera. Since Ruthenian and Serbian coexist in Serbia/Vojvodina, and Serbian presents the majority language, it is most likely that in the future the influence of the Serbian language concerning the terminology of kinship relations in the Ruthenian language will increase. In the language of young Ruthenians, ujo, teta, dever, šure, and other words can already be heard.

\section{References}

ANDRIĆ 2014 = ANDRIĆ Edita: Sličnosti i razlike u terminologiji krvnog srodstva u mađarskom i srpskom jeziku. In: DuDok Miroslav (ured.): Diskursi manjinskih jezika, književnosti i kultura u jugoistočnoj i srednjoj Evropi II. Novi Sad: Filozofski fakultet, 2014. 9-17.

LALIKOVÁ 1989 = LALIKOVÁ Tatiana: O staršej slovenskej príbuzenskej terminológii. Slovenská reč 54 (1989): 88-96.

Makišova-TYrova 2015 = MAKIŠova Anna, TYrova Zuzana: Vyznam a použivanie terminov na označovanie pribuzenskych vztahov v slovenčine u žiakov osmeho ročnika zakladnej školy vo Vojvodine. In: ANDRIĆ Edita (ured.): Iz riznice multijezičke Vojvodine. Jezik-kultura-društvo: sistem rodbinskih odnosa u jezicima nacionalnih zajednica u Vojvodini. Novi Sad: Pedagoški zavod Vojvodine, Filozofski fakultet, 2015. 7-32.

MARJANOVIĆ-SAVIĆ 1982 = MARJANOviĆ Ana, SAVIĆ Svenka: Usvajanje i razumevanje termina za označavanje rodbinskih odnosa kod školske dece. Prilozi proučavanju jezika 18. Novi Sad: Filozofski fakultet, 1982. 27-32.

SAviĆ-RADOviĆ 2014 = SAVIĆ Svenka, RADOvić Danijela: Upotreba i značenje termina za označavanje rodbinskih odnosa učenika VIII razreda osnovne škole: srpski jezik. In: SAVIĆ Svenka, RADović Danijela (ured.): Iz riznice multijezičke Vojvodine. Jezikkultura - društvo: sistem rodbinskih odnosa u jezicima nacionalnih zajednica u Vojvodini. Novi Sad: Pedagoški zavod Vojvodine, Filozofski fakultet, 2014. 13-45. 
VUKOVIĆ 1980 = VuKOvIĆ Gordana: Nazivi za obeležavanje srodnika. In: Kontrastivna jezička istraživanja. Zbornik radova. Novi Sad, 7. i 8. december 1979. Novi Sad: Filozofski fakultet, 1980. 253-265.

БЈЕЛЕТИЋ 1994 = БЈЕЛЕТИЋ Марта: Терминологија крвног сродства у српскохрватском језику. Јужнословенски филолог 50. Београд: Институт за српски језик САНУ, 1994. 199-207.

МАКишовА 2004 = МАКишовА Ана: Називи за обележавање родбинских односа у словачком и српском језику. Славистика 8 (2004): 155-163.

РАмАч 1983 = РАмач Юлиян: Руска лексика. Нови Сад: Универзитет у Новим Садзе, Филозофски факултет, Катедра за руски язик и литературу, 1983.

РАМАч 1995-1997 = РАМАч Юлиян, ФЕЙСА Михайло, МЕДєшИ Гелена: Српско-русински речник / Сербско-руски словнїк I-II. Београд-Нови Сад: Завод за учебнїки и наставни средства - Универзитет у Новом Садзе, Филозофски факултет, Катедра за руски язик и литературу - Дружтво за руски язик и литературу, 1995-1997.

РАМАч 2002 = РАМАч Юлиян: Граматика руского язика. Београд: Завод за уџбенике и наставна средства, 2002.

РАМАч 2010 = РАМАч Юлиян, Тимко-Дїтко Оксана, МЕДєши Гелена, ФЕйсА Михайло: Руско-сербски словнїк / Русинско-српски речник. Нови Сад: Универзитет у Новом Садзе, Филозофски факултет, Катедра за руски язик и литературу - Завод за културу войводянских Руснацох, 2010.

ФеЈСа 2010 = ФЕЈСА Михајло: Нова Србија и њена русинска мањина / Нова Сербия и єй руска меншина / The New Serbia and Its Ruthenian Minority. Нови Сад: ИК Прометеј-КПД ДОК, 2010.

ФЕЈСА 2012 = ФЕЈСА Михајло: Ословљавање у русинском језику: ословљавање у двојезичној основној школи у Куцури / Ословйованє у руским язику: ословйованє у двоязичней основней школи у Коцуре. In: Zbornik Pedagoškog zavoda Vojvodine 8. Iz riznice multijezičke Vojvodine. Novi Sad: Pedagoški zavod, 2012. 168-187.

ФЕЙСА 2014 = ФЕйСА Михайло: Употреба и значенє терминох за родзински одношеня школярох VIII класох основней школи у Войводини: руски язик. In: SAVIĆ Svenka, RADOvić Danijela (ured.): Iz riznice multijezičke Vojvodine. Jezik - kulturadruštvo: sistem rodbinskih odnosa u jezicima nacionalnih zajednica u Vojvodini. Novi Sad: Pedagoški zavod Vojvodine, Filozofski fakultet, 2014. 93-128.

ХоРњАК 2006 = ХоРњАК Михајло: Бачко-сремски Русини. In: ФЕйСА Михайло (ред.): Pусини / Pуснаци / Ruthenians (1745-2005) I. Нови Сад: Филозофски факултет, Одсек за русинистику, ИК Прометеј-КПД ДОК Куцура, 2006. 23-73. 